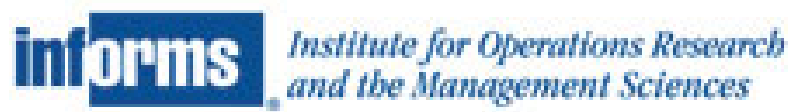

Equity and the Technology Transfer Strategies of American Research Universities Author(s): Maryann Feldman, Irwin Feller, Janet Bercovitz and Richard Burton Reviewed work(s):

Source: Management Science, Vol. 48, No. 1, Special Issue on University Entrepreneurship and Technology Transfer (Jan., 2002), pp. 105-121

Published by: INFORMS

Stable URL: http://www.jstor.org/stable/822687

Accessed: 28/06/2012 21:24

Your use of the JSTOR archive indicates your acceptance of the Terms \& Conditions of Use, available at http://www.jstor.org/page/info/about/policies/terms.jsp

JSTOR is a not-for-profit service that helps scholars, researchers, and students discover, use, and build upon a wide range of content in a trusted digital archive. We use information technology and tools to increase productivity and facilitate new forms of scholarship. For more information about JSTOR, please contact support@jstor.org. 


\title{
Equity and the Technology Transfer Strategies of American Research Universities
}

\author{
Maryann Feldman • Irwin Feller • Janet Bercovitz • Richard Burton \\ Whiting School of Engineering, Johns Hopkins University, Baltimore, Maryland 21218 \\ Department of Economics, Pennsylvania State University, University Park, Pennsylvania 16802 \\ The Fuqua School of Business, Duke University, Durham, North Carolina 27708 \\ The Fuqua School of Business, Duke University, Durham, North Carolina 27708 \\ maryann.feldman@jhu.edu • iqf@psu.edu・janetb@duke.edu・rmb2@mail.duke.edu
}

\begin{abstract}
A merican universities are experimenting with new mechanisms for promoting the commercialization of academic research and generating revenue from university intellectual property. This paper discusses mechanisms available to universities in managing the commercialization of intellectual property, considering equity as a technology transfer mechanism that offers advantages for both generating revenue and aligning the interests of universities, industry and faculty. Employing data from a national survey of Carnegie I and Carnegie II institutions, we document the recent rise in university equity holdings. We present and estimate a model that considers the university's use of equity to be a function of behavioral factors related to the university's prior experiences with licensing, success relative to other institutions, and the organization of the technology transfer office, as well as structural characteristics related to university type.

(University-Industry Relationships; Equity Financing; Academic Patents; Licensing; Technology Transfer)
\end{abstract}

\section{Introduction}

American universities are experimenting with new mechanisms for promoting the commercialization of academic research and generating revenues from university intellectual property. The 20 years since the passage of the Bayh-Dole Act have witnessed a search to optimize, or, more pragmatically, to balance the objectives of managing intellectual property rights, developing new revenue sources, and accommodating faculty interests while simultaneously maintaining norms related to the conduct of academic research and the dissemination of research findings. Based on their own experiences with patent and licensing activities as well as from lessons learned from the experiences of other institutions, universities have experi- mented with, and embraced, alternative mechanisms of intellectual property transfer.

Equity positions in companies, as a payment for the use of university intellectual property, are one emerging mechanism. Agreements in which a university takes an equity interest in a company in exchange for providing the company the right to use university intellectual property is becoming common. ${ }^{1}$ The Association of University Technology Managers (AUTM) first reported on this trend in 1995. In 1999, 79 of 190 institutions responding to the AUTM survey had

\footnotetext{
${ }^{1}$ This paper is not about direct monetary investment in companies or investments in venture capital firms, some of which in turn may invest in start-up firms based on university-based research (Desruisseaux 2000).
} 
taken equity positions in 243 firms (AUTM 1999). Our survey of research universities, conducted in Spring 2000 shows that 1978 was the earliest date reported for an equity deal. By 1992, 40\% of our respondents were taking equity in companies licensing their technology, and, in 2000, 70\% had participated in at least one equity deal (see Figure 1). While equity was initially conceived as a last resort means of accepted payment reserved for cash-starved start-up firms, the use of equity now extends to more established companies as part of a diversified compensation scheme.

The number of universities using equity licensing transactions, coupled with the emergence of equity in a more diversified set of bargaining situations, suggests some strategic net advantages. By net advantages, we mean comparisons of the costs and benefits of equity positions relative to the costs and benefits of alternative technology transfer revenuegenerating options. University technology transfer operations have multiple objectives as determinants of intellectual property strategy. Faculty retention, closer university-industry linkages, enhanced university prestige, and, more generally, enhanced and accelerated technology transfer for the social and economic benefit of the national or regional economy are core objectives named by university respondents (Thursby et al. 2001). As no single technology transfer mechanism may ideally suit these multiple objectives, universities are experimenting with different mechanisms.
In this paper, we describe three advantages to taking equity positions in lieu of licensing fees that interviewees cited as important from the perspective of the university. First, equity provides a university with options or financial claims on a company's future income streams. The attractiveness of the option is consistent with the uncertainty associated with the technical and economic characteristics of academic patents and with the experience-based assessment that the opportunity cost of foregone license and royalty revenue is generally low. Second, equity deals, in which the university becomes part owner of the company, are reported by our interviewees to align the interests of the university and the firm towards the common goal of commercializing the technology. Equity also may mitigate the potential for disputes and litigation about intellectual property between the university and the industry and the potential for conflicts of interest that can arise if a faculty member shifts loyalty away from the university and towards the company developing their intellectual property (Jensen and Thursby 2001). Third, according to our interviewees, equity may serve a certification function that provides a signal to relevant third parties. From the perspective of the university, taking equity may signal to the outside world that the university is entrepreneurial. For the firm, an equity deal may signal to other investors that the firm has received a valuable technology from the university and that the university is confident in the value of technology that

Figure 1 More Universities Take Equity Interests: Year of First University Equity Deal $(n=67)$

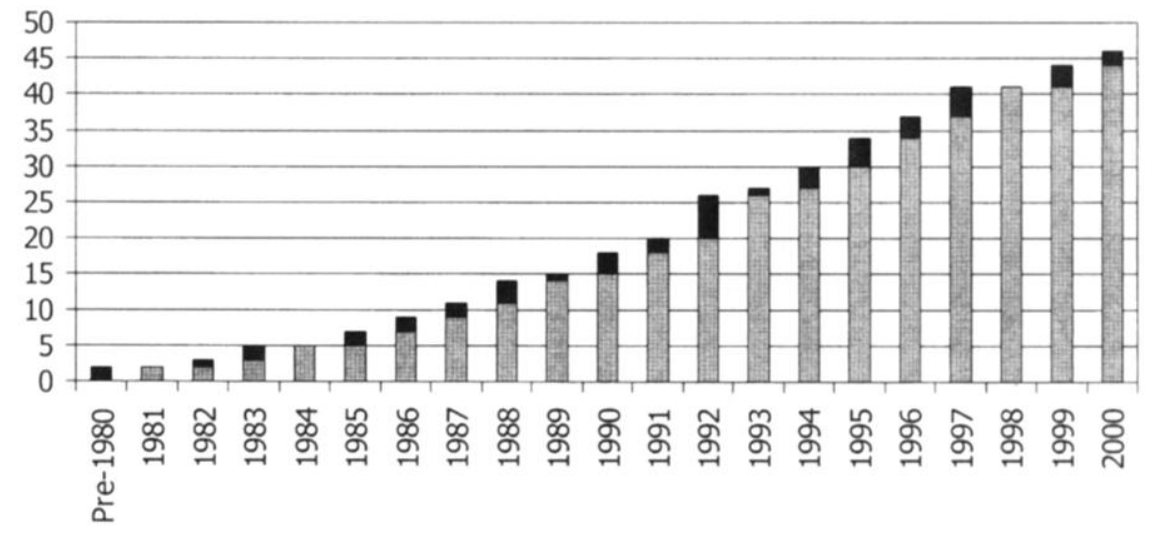

Previous Years $\mathbf{a}$ Current Year 
the firm holds. This may enhance the firm's ability to receive additional funding.

Interviewees also noted the risks and negative aspects of taking equity besides those associated with low or zero economic payoff. On many campuses, the decision to take equity occurred only after considerable debate about the propriety of extending the university involvement in the commercialization of academic knowledge into holding direct ownership stakes in firms. Some critics saw equity holdings as increasing the risk that the university might be held liable or suffer from adverse publicity for product defects. The claimed benefit of improved alignment with the interests of a firm was also seen as lending credence to charges that the university was losing sight of its traditional role as a generator of knowledge as a public good and as an independent societal source of expertise on complex scientific and technical issues. The following discussion of the relative attractiveness of equity and licensing as compensation mechanisms abstracts from these considerations.

Cataloguing the pros and cons of alternative mechanisms, however, is essentially a static task. Technology transfer officials expressed many of these same assessments about the relative attractiveness of equity and licensing in the mid-1980s (Feller 1990). Few, however, entered into equity arrangements at that time. Drawing on data from a survey of Carnegie I and II research universities, we offer a set of findings about the spread of equity holdings among universities and the patterns that exist among universities in their willingness to use the equity mechanism. The conceptual model we develop treats the move to equity as an adaptation to the problems and inadequacies of traditional licensing agreements. Our inquiry is cast in terms of a model of institutional change and adaptation conditioned by learning and the diffusion of best practices, and organizational incentives and behavior.

\section{Why Equity Has Emerged As a Technology Transfer Mechanism}

The provisions of the Bayh-Dole Act established universities' property rights over federally funded inventions and encouraged universities to actively promote the transfer of those inventions to commercial use. The initial university response was to create technology transfer offices to secure intellectual property rights through patents, and endeavor to sell rights to use those patents to firms. Three patterns have emerged. First, the number of patents received by universities increased to the point where 3,151 patents$5 \%$, of the U.S. total patents in 1998-were granted to universities. Second, the number of universities receiving patents has increased (Henderson et al. 1998, Mowery and Ziedonis 1999). This corresponds to an increase in the number and size of university technology transfer offices (Association of American Universities 1986, Seigel et al. 1999, Rogers et al. 2000, Thursby et al. 2001). Third, and most important to this inquiry, the mechanisms used to transfer technology and to attain revenue from intellectual property rights have changed and evolved. These changes reflect the greater sophistication and learning that have come with the experience derived from each university's own involvement in patent and licensing as well as lessons learned from the experience of other institutions. The purpose of the next section is to consider university experience with traditional licensing agreements and then evaluate the reasons for the growing adoption of equity deals.

\section{Licensing Reconsidered}

Licensing agreements typically involve selling a company the rights to use a university's inventions in return for revenue in the form of upfront fees at the time of closing the deal, and annual, ongoing royalty payments that are contingent upon the commercial success of the technology in a downstream market. The terms of the licensing agreement depend upon the assessment of the value of the technology in a product market that is often uncertain and thus difficult to evaluate. While there are some standards, many provisions of the royalty agreement are negotiated. Bray and Lee (2000) report that license issue fees typically range from $\$ 10,000$ to $\$ 50,000$ but may be as high as $\$ 250,000$, while royalty rates are typically $2 \%$ to $5 \%$ but may be as high as $15 \%{ }^{2}$ The bargaining power of the two parties may be very

\footnotetext{
${ }^{2}$ This is the same range reported by Feller (1990).
} 
uneven depending upon such factors as their relative sophistication, experience and resources, established industry-specific yardsticks, and the perceptions of the attributes of the technology, such as its commercial promise and distance to market. As a result, the deals negotiated between one firm and several universities or between one university and its licensees may be very different.

There are many positives to university technology licensing. First, an active license program has both substantive and symbolic importance: It attests to the capabilities of universities to advance technology and to serve as an engine of growth for both national and local economies. Second, an active technology transfer organization (TTO) with a large number of active licenses has become an instrument that the university can use in recruiting and retaining faculty. ${ }^{3}$ Interviews with TTO officials at several universities indicate that some prospective faculty seek meetings with these officials to determine if the university is a congenial home to their prospective entrepreneurial activities.

Current trends in patents and licensing suggest mixed patterns, however. The continuing upward annual trend in patents, licenses, and license revenues reported in the AUTM 1999 survey suggests that academic licensing still is growing, with most institutions reporting more licensing revenue than they did the previous year. ${ }^{4}$ Still, there is evidence that despite these rising totals, traditional licensing as a technology transfer mechanism has not yielded major financial returns for most institutions.

Efforts by universities to secure revenues from licensing have been hindered by the fact that the standards for securing patents for intellectual property

\footnotetext{
${ }^{3}$ The right of faculty to share in the licensing revenue was a provision of the Bayh-Dole Act. Although substantial royalty windfalls have been reported for a small number of faculty, the after-tax return to faculty from royalties in general has been reported as relatively disappointing, comparing unfavorably with the revenue that faculty earn from consulting (Blake 1993).

${ }^{4}$ For the 82 recurrent respondents that reported data for the period FY 1991-FY 1999, the total increased from $\$ 149$ million to $\$ 655$ million. These revenues, while small in comparison with other university revenue sources, are not insignificant.
}

are not equivalent to the requirements for commercial success. ${ }^{5}$ In a recent survey of technology transfer officers, Jensen and Thursby (2001) found that only about $12 \%$ of the licensed technology is ready for commercialization. The majority of licensed technology requires significant developmental work and ongoing cooperation by faculty to realize commercial success.

Only a small subset of invention disclosures generate any licensing interest; of those that do, very few generate sizeable net returns. The rule of thumb in university technology transfer is that for every 100 invention disclosures, 10 patents and 1 commercially successful product result (Blake 1993). The distribution of licensing revenues is highly skewed with a few big commercial successes generating large returns for a small number of universities. Wellknown licenses. such as the Cohen Boyer gene splicing technique (University of California and Stanford), Gatorade (University of Florida), Cisplatin (Michigan State), Fax technology (Iowa State), or Taxol (Florida State University) are the exceptions rather than the rule. $^{6}$

Finally, biomedical invention accounts for a substantial share of academic licenses (Mowery et al. 1999, Feller et al. 2000), and commercialization of these products requires navigating the U.S. Food and Drug Administration approval process, which takes an average of 10 years. Considering that additional development is needed to convert the licensed technology into a viable product before a firm even can begin the long approval process, long lag times exist before the receipt of any royalties by the university. ${ }^{7}$ Equity, in contrast, may provide a financial return in

\footnotetext{
${ }^{5}$ The basic principle is well known. For example, as articulated by Niels Reimers, formerly of the Office of Technology Licensing, Stanford University: "The bad news is that the technology is underdeveloped and unproven, and a significant investment is required by the company for development and ultimately may be unsuccessful for market or technological reasons. The good news is that often a basic patent position will be available" (Reimers 1989).

${ }^{6}$ Taxol, for example, the patent owned by the Florida State University, has worldwide annual sales worth $\$ 1.2$ billion and is expected to yield $\$ 60$ million in licensing revenue this year (Zacks 2000).

${ }^{7}$ Indeed, several of our survey respondents expressed frustration with licensing as a transfer mechanism due to this time lag.
} 
the case of an Initial Public Offering or an acquisition by another firm.

Further, there is evidence that licensing has not been an entirely satisfactory mechanism from the industry perspective, either. In a survey of industry licensing executives, Thursby and Thursby (2000a) found that $66 \%$ (199 business units out of a total of 300 ) had not licensed intellectual property from universities. The reasons given included the feeling that university research is generally at too early a stage of development $(49 \%)$; that universities rarely engage in research in a related line of business (37.4\%); university refusal to transfer ownership to company (31\%); university policies regarding delay of publication are too strict (20\%); and concerns about obtaining faculty cooperation for further development of the technology $(16 \%){ }^{8}$ In sum, there is evidence of industry reluctance to licensing.

\section{Equity Considered}

In the immediate post-Bayh-Dole period, university technology transfer offices generally considered equity-based licenses to be a compensation mechanism of last resort reserved for cash-starved, startup firms. "Start-ups rarely have a positive cash flow during their first years of operation; therefore, taking equity in such start-ups partially in lieu of cash fees is an important technique to conserve the company's cash for investment in product development" (AUTM 1999, p. 17.) Although relative to the fixed upfront fees and standard royalty rates of traditional licenses, equity held the promise of enabling the university to share in potentially larger revenues if a licensee flourished as a result of use of the university's patents, these revenues were perceived to be highly uncertain. The high failure rate of new firms was well known. Acting as would be predicted by the well-established certainty effect (Kahneman and Tversky 1979, Tversky and Kahneman 1992), technology transfer officers valued the relatively certain expected revenues accruing from traditional licenses more than the uncertain,

\footnotetext{
${ }^{8}$ Twenty-eight percent of the respondents indicated some other difficulty such as "general attitude is poor," "complexity of deal and... weird expectations," "too cumbersome" and "high licensing fees" Thursby and Thursby (2000a).
}

though potentially higher, expected revenues associated with equity deals.

With the exception of a few universities such as MIT that made equity a core part of its technology transfer and licensing portfolio, most universities at first accepted equity deals in those cases where the university believed that a patent had economic value but no established firm was able to pay the required fees and royalties of a traditional license. ${ }^{9}$ Even if the expected returns did not materialize, the university might still realize value by advancing its objectives of disseminating knowledge, getting the technology out for commercialization, and, in some cases, accommodating the interests of the faculty inventors. ${ }^{10}$

Our interviews with technology transfer officers suggest that this perception of equity as the mechanism of last resort has changed. Three main factors appear to underlie this evolution. The first is the increased experience of TTOs with traditional licensing. This has resulted in a greater understanding of the limitations of this transfer mechanism in terms of a downward revision in expectation about licensing's revenue-generating potential. ${ }^{11}$ In contrast, equity is perceived to offer an advantage as the potential return

${ }^{9} \mathrm{JHU}$ took its first equity deal in 1993 for the use of intellectual property that was licensed to a firm called CardioLogic. Larger firms had been approached but were not interested in the technology, which faculty and TTO staff believed was an important invention. The only mechanism that would allow the technology to be licensed was an equity deal with a start-up firm.

${ }^{10}$ Duke University's involvement in one of early equity deals in 1987 follows such a scenario. Though the faculty inventor expressed strong interest in taking the technology to a start-up of his own, the university insisted on first trying to license it to an established firm. They were successful in this. However, the license was subsequently reacquired from the initial licensee-a large, established pharmaceutical company-due to the company's failure to move the technology forward. At that point, the university still chose to spend an additional year seeking to make a deal with another established firm before accepting a license-for-equity deal with the firm established by the inventor.

${ }^{11}$ The earliest university licenses were granted on an exclusive basis that provided no limits on the company's use of the intellectual property. Exclusive licenses gave the company total control over the INTELLECTUAL PROPERTY in all potential applications, markets and adaptations. However, our interviews revealed that increasingly licenses are nonexclusive with stipulated limits on technology application, geographic scope or terms of use. 
is based on the total assets of the firm, which is expected to be greater than the return to any individual product. Second, TTOs, as well as firms, have begun to appreciate the mutual benefits of equity in aligning university-firm interests. Third, interviewees believe that equity more so than licensing provides prestige and legitimacy for both the university and the firm. We discuss these arguments within the context of pertinent theoretical frameworks in the sections below.

\section{The Upside Revenue Potential of Equity}

In discussing the advantages of equity-based licenses, many of our respondents cited the upside potential of this transfer mechanism. Through equity, the university has the opportunity to benefit from future products or processes that increase the technical and economic value of the firm. This view of equity is not new; however, for several reasons the perceived value of equity has increased over the past 10 years compared to the value ascribed to traditional licensing. First, as discussed, many universities have been disappointed by the revenue-generating performance of their traditional licenses. Not only have relatively fewer inventions resulted in licenses than had been hoped, but also the majority of these licenses have provided only moderate, if any, returns. The opportunity cost of taking an equity option is the forgone revenues that the university could receive had it negotiated a traditional license with upfront fees, milestone payments, and running royalties. Given that universities have learned from their own experiences and the experiences of other universities that this opportunity cost is, on average, relatively low, the decision to trade traditional licensing revenues for equity holdings has become more attractive.

Second, many respondents noted that equity has the advantage in providing the university with an opportunity to share in the fortunes of a firm rather than just in the fortunes of a technology that may have contributed to the development of the firm but did not directly result in a commercial product. While traditional licensing agreements are specific to the use of a particular patent, equity deals provide a means for the university to share in the company's success even in the event that no licensing royalties accrue to the original technology. The technology covered by university patents and licenses are typically far away from the commercial market and may not result in a viable commercial product. However, a firm's experience with the licensed technology may provide knowledge that is incorporated into subsequent products and materially contribute to the company's ultimate commercial success. Equity deals permit the university to capture at least some of the returns associated with such knowledge transfer. In the worst-case scenario-where the original technology proves to be completely worthless-the university still can benefit from an equity deal if the selected partner proves viable. Equity holdings yield a portfolio that captures a broad range of potential futures. In this respect, equity has come to be perceived as being less risky than traditional licenses.

Third, there is a broader recognition that holding an equity position permits the university to buy time, waiting to exercise its option (i.e., sell its equity) until uncertainty about the economic value of its patent holdings is reduced (Vonortas and Hertzfeld, 1998). Again, academic patents typically are early-stage technological developments characterized by high degrees of technical and market uncertainty. To bring the technology under an academic patent to market often requires considerable follow-on research, as well as additional costs for approval (in the case of drugs), production, and distribution. With a traditional license, the university has little option but to negotiate the upfront fees, milestone payments, and fixed royalty rates in the shadow of this uncertainty. To deal with such uncertainty, the universities tend to adopt standard industry-specific running royalty rates, or to rely on technology licensing officials with expertise in selected technological fields. The first technique drives the institution's negotiating position to the average rate of return for licenses in a field, while the latter entails additional administrative costs. In fact, the latter is feasible only for those institutions with sizeable numbers of patents, clustered into discernible utility or industry classes. Employment of either of these techniques effectively reduces overall licensing returns. In comparison, equity deals look relatively more attractive. If the company has an Initial Public Offering or is acquired before achieving 
a marketable product equity may provide a shorter time horizon to revenue realization.

Finally, it must be noted that for most of the 1990s - the period when university equity holding increased-the performance of the stock market, and of technology stocks in particular, had been quite positive. ${ }^{12}$ University personnel, evaluating the potential of equity against this backdrop, were likely to perceive the returns of equity to be quite promising.

\section{The Incentive Alignment Value of Equity}

Another recurring theme that emerged from our discussions with technology-transfer officers was the view that equity more so than licensing was a means to align the interests of the university and the licensing firm. Three aspects of alignment were stressed: (1) common goals related to the appreciation of the value of the firm and the commercialization of the technology; (2) relative ease of initial contractual negotiations; and (3) provision for ongoing, within agreement, decision-making and adjustment. Each of these is discussed in turn.

Several technology transfer officers emphasized the benefits provided by equity-based licenses by aligning the long-term interests of the firm and the university. With equity, both parties gain as the total value of the licensed technology, as well as the firm as a whole, increases. As such, it is in the best interests of both parties to take actions that enhance the probability of the firm's commercial success. TTO officials view this goal alignment as smoothing existing and future university-firm technology transfer transactions. As noted by one respondent, a firm that has executed an equity-based license can expect to find the going much easier in subsequent negotiations to sponsor research with, or acquire additional technology rights from, the university. Rather than play hardball in hopes of structuring the best possible one-time, stand-alone deal, the university - evaluating the new deal in light of its existing ties-is more likely to strive to expedite the transaction in a manner that enhances firm viability.

\footnotetext{
${ }^{12}$ Interviews were conducted in Summer 2000 before the sharp decline in the stock market in the second half of the year market.
}

A number of respondents also highlighted the comparative ease of constructing an equity-based licensing agreement as compared to the challenge of negotiating a traditional license. Traditional licenses are, in essence, contracts that specify price, detailed by level of royalty rates and upfront fees, performance requirements as reflected in milestone payment terms, and enforcement rights executed through the courts. An equity-based license changes the focus from contracting on price and performance to agreeing on ownership shares (i.e., how much stock does the university receive for the right to use the technology?).

Our interviewees suggest that it is easier to agree on the latter than the former. ${ }^{13}$ Specifically, equity agreements are easier to write as they center on the delineation of property rights and do not involve the specification of the large number of contingency terms that a traditional license does. Equity also is reported to have an advantage over traditional licensing in that it reduces the potential for litigation relating to the firm's use of the licensed technology. Consider a case in which a firm draws upon a university license in its evolving efforts to develop a commercially viable product, all the while modifying, scrapping, and extending elements of the technology. Each modification opens up new potential for legal conflicts about the extent to which the final product makes use of the licensed technology. As the original contract rarely completely (or even significantly) anticipates these developments, there are seldom payment and/or performance terms on point. To resolve disputes, the university and firm may attempt to renegotiate in good faith. However, such renegotiations, given the zero-sum nature of royalty payments, may be contentious, break down, and lead to litigation. In an equity deal, contribution disputes are less likely to produce this outcome as both players share in all value created.

\footnotetext{
${ }^{13}$ Though prior to taking a first equity deal, there is often contentious debates at the university about the proper role of the university and the general framework for all future equity deals, these deliberations generally come before the university sits down to negotiate with an individual firm. Interviewees tell us those subsequent firm-university negotiations, given the focused nature of the negotiation on a particular deal, is generally straightforward.
} 
The example of The Pennsylvania State University and AbioMed illustrates this point. Penn State took equity in AbioMed, a 19-year-old biomedical firm in Boston, in exchange for giving the company the rights to use artificial heart technology developed at the Hershey Medical School. AbioMed was working on a product that would have inevitably been a competitor to the Hershey Heart. Equity became the preferred compensation mechanism for both parties because it facilitated the integration of the company's on-going research and development work with Penn State intellectual property while avoiding potential future legal complications.

\section{The Legitimacy Value of Equity}

A final benefit of equity-based licenses cited by respondents is the belief that it provides legitimacy and or prestige for both the firms and the university. In discussing why firms seek equity deals, several of the technology transfer officers interviewed noted that beyond the obvious benefit of conserving cash, firms believe university equity holding enhanced their credibility. ${ }^{14}$ Lerner (1999) concludes that firms participating in the government Small Business Innovation Research (SBIR) program grew significantly faster than comparable firms and were more likely to attract venture capital financing indicating the government funding conferred a halo effect. A similar halo may be generated by a university ownership position. Specifically, our interviews reveal that a university's willingness to accept equity in lieu of up-front fees and/or royalties is believed to provide a

\footnotetext{
${ }^{14}$ Evidence about the existence and direction of legitimacy effects of equity holdings is indirect and mixed. Shane (2000) in a study of MIT patents however points to a negative relationship between university equity holdings and the successful commercialization of the technology covered by the relevant license. The reasoning behind this finding involves a restatement of the mainstream motivation for why universities take equity: No existing firm believes that the patented technology is commercially profitable. Start-up firms that seek to commercialize such technologies are inherently highly risky enterprises. Our focus in this paper does not displace these dynamics. The belief, on the part of the firm, that having a university as an equity partner adds legitimacy to the firm's ventures is not a guarantee that the firms will succeed. Exuberant spirits may exist on both sides of the bargaining table.
}

signal to capital markets and potential strategic partners that the university has made a positive evaluation of the worthiness of the technology and the firm's development competencies. If this signal is perceived as valuable, it may give the university some advantage in the equity share negotiations and thus enhance its returns.

Perhaps more salient for our goal of understanding universities' use of the equity mechanism is the prestige value that technology transfer personnel believe that having active licenses conveys to the university. The university's willingness to take equity lowers the cost of licensing the technology and this may generate more licensing activity. We therefore might expect that universities with low levels of licensing activity, both in absolute and relative terms, to adopt taking equity as a means to increase their measured level of technology transfer activity. Further, there is also a perceived halo effect of university equity positions. Universities with a high number of equity deals generally gain an affirmative reputation for being progressive and entrepreneurial.

In conclusion, equity appears to provide an improved mechanism for university technology transfer. Although equity options are not without problems, our interviews reveal that university officials find that equity offers some advantages over traditional licensing agreements based on up-front fees and royalty payments. The next section develops a set of hypotheses that relate university characteristics to the adoption of equity and presents data that we will use to test these hypotheses.

\section{Hypotheses and Data}

Writing just after Johns Hopkins University took its first equity interest, David Blake, Senior Associate Dean of the School of Medicine, wrote "Most universities and their trustees are quite comfortable with accepting royalty payments and sharing them with faculty inventors under approved formulas. They are much less comfortable with holding stock in a company that is commercializing a university discovery (Blake 1993, p. A52)." As noted previously. we have seen a recent increase in the use of equity in technology transfer. Logically, one can attribute this increase 
in the number of equity transactions to the perceived attractiveness of this mechanism, as described above. However, substantial variation exists in both the timing of first equity deals and the intensity of equity involvement across the universities in our sample. The remaining question, and the one we tackle in this section, is what factors explain these differing adoption strategies?

We propose a model in which the intensity of a university's equity involvement is related to a set of behavioral and structural variables. The behavioral variables relate to intra- and interinstitutional learning and adaptation that come with time and experience. The control variables include the Carnegie Classification of the university, the status as a public or private entity, and the affiliation with a medical school.

\section{Direct Technology Transfer Office Attributes: Experience and Structure}

One strong association that emerged from our interviews was that of the relationship between technology-transfer experience and the perceived attractiveness of equity as a technology transfer mechanism. In general, we observed that experience with traditional licensing give rise to dissatisfaction with this technique and subsequent experimentation with new mechanisms. Hands-on experience seemed to expose previously unconsidered limits of traditional licensing. As TTOs gained experience with traditional licensing mechanisms, they appear to also become more skeptical about the expected returns accruing to this transfer mechanism. This greater understanding of potential limits led to a downward revision of the transfer mechanism's relative attractiveness, which, in turn, appears to create a willingness to experiment with alternative transfer mechanisms, such as equity-based licenses.

In addition, universities that have more experience with industry-sponsored research are expected to have a greater commitment to technology transfer and to be more willing to experiment with new mechanisms that appear to offer perceived benefits. As TTOs gain experience with industry through sponsored research they appear to be more willing to attempt to facilitate increased interaction in technology transfer. Thus, the following hypothesis.
HyPOTHESIS 1. The greater a university's experience with technology transfer, the more likely the university will be to adopt equity-based transfer mechanisms.

Along with licensing experience, we argue that the budgetary policy of the technology transfer office may also influence equity involvement. While we hypothesize that greater experience leads to greater dissatisfaction with traditional licensing, and thus greater interest in equity-based transfer deals, willingness to make this trade-off may be constrained, or secondary, to immediate budgetary needs. Traditional licenses generate both certain and uncertain revenue streams. Up-front fees, the required payments at the origin of a licensing deal, are immediate and certain. Upon completion of negotiations, the university can expect to receive these fees. Specifically, transfer offices that are required to be self-supporting may rely on the immediate and certain revenues coming form the up-front fees of traditional licenses. As noted by March and Shapira (1987), managers are much less likely to take risks when organizational survival is at stake. Thus, the following hypothesis.

HyPOTHESIS 2. The expectation that the technologytransfer office should be self-supporting reduces the propensity for the university to adopt equity-based transfer mechanisms.

\section{Technology Transfer Experience Relative to Other Institutions}

While direct experience is expected to be an important influence in the decision to adopt alternative transfer mechanisms, we also argue that the experience of others also comes in to play. Many of the technologytransfer officers we spoke with volunteered that they commonly benchmark their university's performance against the performance of other similar institutions. The average performance of a cohort comes to represent the minimal acceptable performance level-to either the TTO or those that are evaluating the TTO.

March and Shapira (1987) and March (1988) argue that aspirations or performance targets affect risktaking behavior. This may be extended to reflect the expected influence of traditional license-related performance benchmarks on a university's propensity to enter equity-based licenses. Though expected value 
may be high, equity deals are generally perceived to be more risky than traditional licenses. Equity is riskier because of its relative novelty-few institutions have had any significant experience with this mechanism. In addition, there is greater potential return variance associated with equity. While traditional license returns are somewhat narrowly bound between up-front fees and a percentage of product sales, equity returns vary more broadly from zero, if the firm fails, to some percentage of the firm's total worth.

March and Shapira (1987, p. 1413) argue that managers that are near a performance target will be relatively risk averse. These individuals are expected to avoid a risky action that may cause performance to fall below target. However, when performance exceeds the target by a substantial amount, managers are more likely to engage in risky behavior in hopes of capturing the potential up-side benefit. Thus, the following hypothesis:

Hypothesis 3. Leading performers, those performing substantially above the benchmarked target, will be more likely than average pwformers to adopt equity-based transfer mechanisms.

For decision-makers who have not been successful to date-those performing substantially below target levels-the desire to reach the target will cause them to focus on opportunities associated with the risky action (March and Shapira 1987). Any action that may get them closer to the target is attractive. Because, these managers are currently doing poorly, they do not have much to lose if the gamble fails to play out to their advantage. Thus, these individuals are expected to have a predilection for risk-prone behavior:

HYPOTHESIS 4. Lagging universities, performing substantially below their cohorts, will be more likely than average performers to adopt equity-based technology transfer mechanisms.

\section{Description of Survey Data}

The most cited source on university technology transfer, the AUTM annual survey, first reported data on university equity agreements in 1995 . Over the course of the survey's history, however, AUTM has changed data collection items, adding and dropping variables in response to changes in university practices. The changes limit the usefulness of these surveys to discern trends. As a result, researchers interested in more focused questions have used mail and telephone surveys to collect original data on the equity aspects of university technology transfer activities. Bray and Lee (2000), for example, have compared the amount of revenue received from equity positions versus licensing fees, while Di Gregorio and Shane (2000) have looked at equity as one dimension in considering why some universities generate more start-up firms than others. Our interest is in understanding equity as part of a general examination of the evolving character of university-industry relationships. Thus, as with these other recent studies, our research involved a series of telephone interviews with university technology licensing and transfer officials.

In Summer 2000, we conducted a survey of the 124 Carnegie I and II research universities that have active technology transfer operations. ${ }^{15}$ The letter that introduced the survey was addressed to the head of the TTO as identified by AUTM or the university's web page. We contacted each university official at least three times to attempt to set up the survey interview. The interview protocol asked about university practices related to equity, among other questions related to the organization and function of the TTO. The majority of the 124 institutions (76\%) participated in the AUTM survey on a regular basis.

We received 67 responses, for a response rate of $54 \%$. Comparison of the respondents with the total universe of universities indicates no biases in terms of structural characteristics (e.g., Carnegie Classification, public/private, land grant/non-land grant, medical school/no medical school). Our model estimation is based on 62 observations. Lack of data on some of

${ }^{15}$ Under the Carnegie classification, Research Universities I award 50 or more doctorates each year and annually receive $\$ 40$ million or more in federal research support. Research Universities II are the same as Research I universities except that they receive between $\$ 15.5$ million and $\$ 40$ million annually in federal research support. This classification system will be undergoing major changes in the near future. Only one institution, Howard University, did not have an office of technology transfer or some individual whom we were able to identify as being assigned technology transfer as their primary responsibility. 
the independent variables from sources other than our survey necessitated omitting five institutions from our econometric estimation. Again, we do not find evidence that the estimation sample is biased with respect to any measurable characteristics.

In describing the characteristics of our respondents, we draw upon the full sample of 67 . Of the TTO respondents, $76 \%$ indicated that their university had taken equity in a company. Our findings are similar to those from Thursby et al. (2001), who found that $82 \%$ of their 62 responding universities had taken equity as part of a licensing deal. The similar number of respondents is a coincidence, as the sampling frame of our respondents differ. The lower rate of universities taking of equity in our sample may be a result of the greater institutional diversity in our sample frame.

Thirteen universities (19\% of our respondents), each a public university, were prohibited from taking equity in companies because of state statutes that limit their range of activity. These legislative restrictions do not limit the universities' initiatives to be in a legal position to accept equity, however. Of these universities, 10 formed independent 501(c) 3 entities to manage their intellectual property and to take equity holdings. ${ }^{16}$ To date, seven of these entities have taken equity in lieu of licensing fees for a university invention. Three of the independent entities had not taken equity at the time of our interview.

University officials were asked the total number of equity deals in which they had participated. Our respondent set of 67 universities participated in 679 equity deals. The distribution of the number of deals is highly skewed as shown in Figure 2. The mean number of equity transactions was 10.3 , the median was 5 and the mode was 0 . The maximum number of equity deals was 90 .

Dependent Variable. The dependent variable for our study is the intensity of equity involvement. We measure this variable as the total number of a university's equity interests divided by the number of the university's active licenses for 1998. Active licenses are the cumulative number of licenses that had not terminated by the end of the 1998 .

The total number of equity deals is from our survey, verified against the AUTM survey. The number of active licenses is from the 1998 AUTM survey. For universities that did not routinely participate in

Figure 2 Diversity in Experience with Equity Deals $(n=67)$

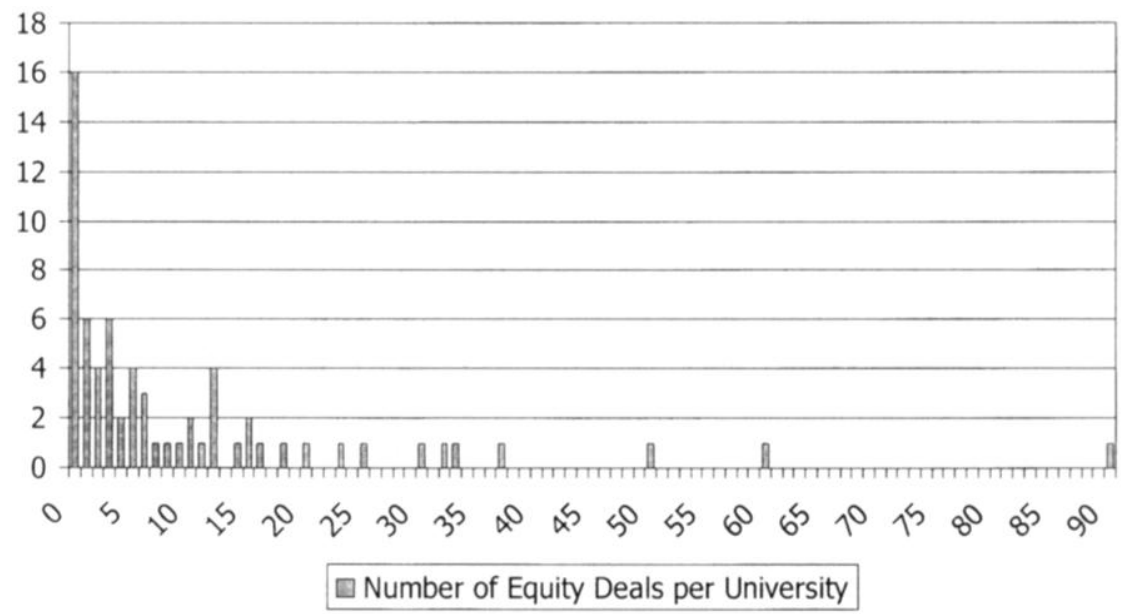

${ }^{16}$ An example is the Ohio State University Research Foundation. Other institutions that have not been subject to statutory limitations have formed this type of entity to serve as a bridging mechanism. For example, the University of Illinois system formed Illinois Ventures as an intermediary institution to focus on commercializing university intellectual property. 
Figure 3 Distribution of the Intensity of the Use of Equity: Equity Deals As a Percentage of All Active Licensing Agreements

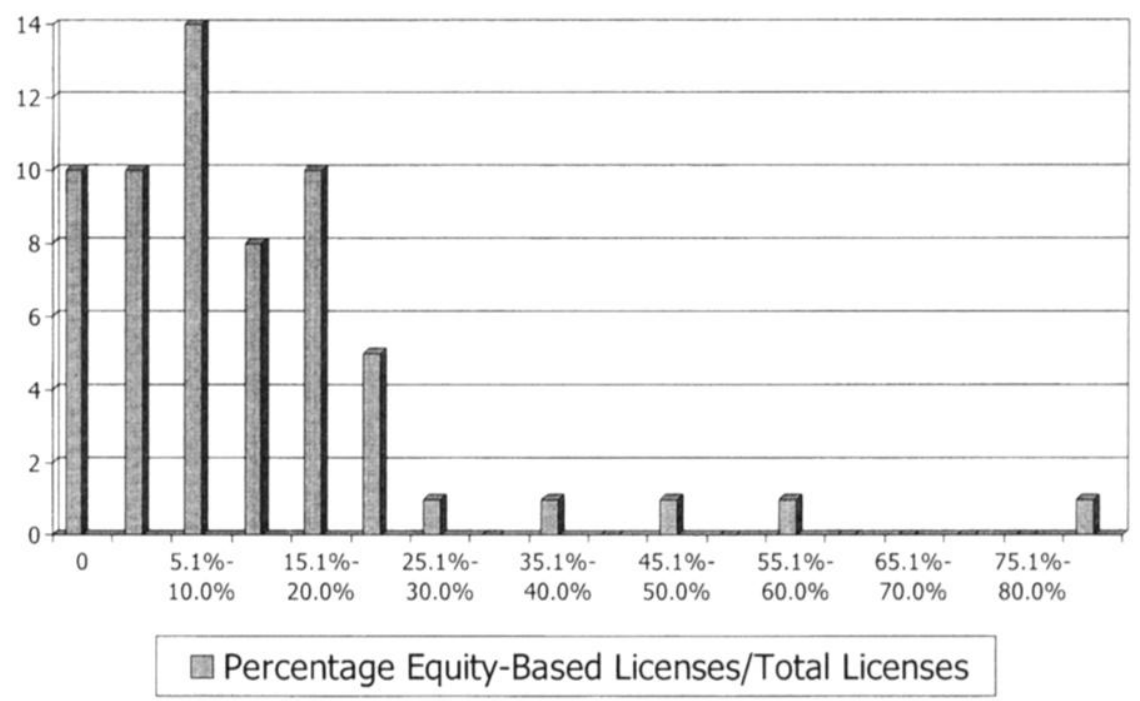

AUTM, we gathered data on the number of active licenses from web pages or from our interviews.

There is variation in the use of equity deals as a percentage of all intellectual property licenses (see Figure 3). For our respondents, the percentage of equity deals accounted for a mean value of $14.4 \%$, and a median of $8.5 \%$. The maximum use of equity was $88.1 \%$ indicating that this respondent used equity for the vast majority of their intellectual property agreements. This last statistic is an artifact of the relatively small number of licensing agreements at this university, as well as to other universities in the upper tail of the distribution. To adjust for this skewnesss, we weight our regression model to mitigate the effect of outliers who appear to have made high use of equity simply because they did not have many licensing opportunities.

Independent Variables. The technology transfer experience of the university provides the independent variable for Hypothesis 1 . We use three measures of experience: (1) age of the technology transfer office; (2) cumulative number of executed licenses (1991-1998); and (3) the log of the cumulative amount of industrial research support received (1991-1998). These data are from the annual AUTM surveys, verified and augmented by our survey and institutional data from the National Science Foundation's Com- puter Aided Science Policy Analysis and Research (CASPAR) database.

For Hypothesis 2, the budgetary structure of the technology transfer office is the independent variable of interest. Using our survey data, we construct a dummy variable equal to 1 if the expectation is that the technology-transfer office will be self-supporting, 0 otherwise. Roughly, half $(47 \%)$ of the respondent offices in our survey had expectations of being selfsupporting.

The university's technology transfer experience relative to others is the independent variable for the final two hypotheses. Our interviews revealed that TTOs are sensitive to the amount of intellectual property activity they have relative to a cohort of similar institutions. Our interviews revealed that status, as either a public or private institution, the presence of a medical school, and some measure of the level of intellectual property income relative to an institution's total $R \& D$ expenditures were considerations in defining one's cohort. Accordingly, we grouped institutions into four cohorts based on status as either a public or private institution and the presence or absence of a medical school: public/with medical school; public/no medical school; private/with medical school; private/no medical school. To construct the cohort variable of licensing income relative to $R \& D$ expenditures we calculated the total annual licensing rev- 
FELDMAN, FELLER, BERCOVITZ, AND BURTON

Equity and Technology Transfer Strategies of American Research Universities

Table 1 Summary of Hypotheses

\begin{tabular}{|c|c|c|c|c|}
\hline Hypothesis & Dependent Variable & Independent Variable & Operational Independent Variable & Predicted Sign \\
\hline \multirow[t]{2}{*}{ Hypothesis 1} & $\begin{array}{l}\text { Equity envolvement } \\
\text { intensity: }\end{array}$ & Own experience & Age of technology transfer office & + \\
\hline & $\begin{array}{l}\text { Total \# of equity interests } \\
\text { Ave. annual active licenses }\end{array}$ & & $\begin{array}{l}\text { Cumulative number of licensing deals } \\
\text { Average annual industrial research support }\end{array}$ & + \\
\hline Hypothesis 2 & $\begin{array}{l}\text { Equity involvement } \\
\text { intensity: } \\
\text { Total \# of equity interests } \\
\text { Ave. annual active licenses }\end{array}$ & Budgetary structure & $\begin{array}{l}\text { Expectation of TTO self-sufficiency } \\
\text { Yes }=1 \text { No }=0\end{array}$ & - \\
\hline Hypothesis 3 & $\begin{array}{l}\text { Equity involvement } \\
\text { intensity: } \\
\text { Total \# of equity interests } \\
\text { Ave. annual active licenses }\end{array}$ & Relative experience & Leading cohort & + \\
\hline Hypothesis 4 & $\begin{array}{l}\text { Equity Involvement } \\
\text { intensity: } \\
\text { Total \# of equity interests } \\
\text { Ave. annual active licenses }\end{array}$ & Relative experience & Lagging cohort & + \\
\hline
\end{tabular}

enues from 1991-1998 relative to the university's total research budget. Considering the distribution of similar institutions, ${ }^{17}$ we classify institutions greater than one standard deviation above the category average as leading their cohort (Hypothesis 3). Similarly, institutions with average annual licensing revenue that was more than one standard deviation below the category mean are classified as lagging their cohort (Hypothesis 4).

Control Variables. In addition to the independent variables, we add controls for university type. Specifically, we create three dummy variables (each with $1=$ Yes, $0=$ No) to delineate whether a university (1) has a medical school; (2) is private; and (3) is classified as a Carnegie I Research Institution.

Table 2 provides descriptive statistics for the variables used in the regression.

\section{Empirical Results}

Table 3 provides our empirical results. The dependent variable is the total number of university equity

${ }^{17}$ To operationalize this measure we first categorized obvious outliers as either leading or lagging their cohort and then calculated the mean values and standard deviations.
Table 2 Descriptive Statistics

\begin{tabular}{|c|c|c|}
\hline $\begin{array}{l}\text { Variable } \\
\text { Equity Share }\end{array}$ & $\begin{array}{l}\text { Mean } \\
\quad 0.1443\end{array}$ & $\begin{array}{c}\text { Standard Deviation } \\
0.1812\end{array}$ \\
\hline \multicolumn{3}{|c|}{ Hypothesis 1: Own Technology Transfer Experience } \\
\hline $\begin{array}{l}\text { Age of technology transfer } \\
\text { office }\end{array}$ & 14.6452 & 10.8493 \\
\hline Cumulative number of licenses & 148.6906 & 218.9944 \\
\hline $\begin{array}{l}\text { Cumulative number of } \\
\text { licenses-squared }\end{array}$ & $69,293.94$ & $208,772.6573$ \\
\hline $\begin{array}{l}\text { Log of average annual } \\
\text { industrial research support }\end{array}$ & 13.7728 & 3.7624 \\
\hline \multicolumn{3}{|c|}{ Hypothesis 2: Technology Transfer Budgetary Incentives } \\
\hline $\begin{array}{l}\text { Expectation that TTO will be } \\
\text { self supporting }\end{array}$ & 0.4677 & 0.5030 \\
\hline \multicolumn{3}{|c|}{ Hypothesis 3: Relative Technology Transfer Experience } \\
\hline Lagging cohort & 0.2742 & 0.4497 \\
\hline Leading cohort & 0.2258 & 0.4215 \\
\hline \multicolumn{3}{|l|}{ Control Variables } \\
\hline Has medical school & 0.5484 & 0.5017 \\
\hline Private university & 0.3226 & 0.4713 \\
\hline Is Carnegie I institution & 0.6613 & 0.4771 \\
\hline
\end{tabular}


Table 3 Empirical Results

\begin{tabular}{|c|c|c|c|}
\hline Own Technology Transfer Experience & Model 1 & Model 2 & Model 3 \\
\hline Age of technology transfer office & $\begin{array}{l}0.0296 \\
(0.0107)^{* *}\end{array}$ & $\begin{array}{l}0.0249 \\
(0.0131)^{* *}\end{array}$ & \\
\hline Cumulative number of licenses & $\begin{array}{l}-0.6924 \\
(0.1198)^{* *}\end{array}$ & $\begin{array}{c}-0.0073 \\
(0.020)^{* *}\end{array}$ & \\
\hline Cumulative number of licenses-squared & & $\begin{array}{c}4.80 \mathrm{e}^{-06} \\
\left(1.6 \mathrm{e}^{-06}\right)^{* *}\end{array}$ & \\
\hline $\begin{array}{l}\text { Log of average annual industrial } \\
\text { research support }\end{array}$ & & $\begin{array}{l}0.2524 \\
(0.1478)^{*}\end{array}$ & \\
\hline \multicolumn{4}{|l|}{ Technology Transfer Budgetary Incentives } \\
\hline $\begin{array}{l}\text { Expectation that TTO will be self } \\
\text { supporting }\end{array}$ & $\begin{array}{l}-0.400 \\
(0.2416)^{*}\end{array}$ & $\begin{array}{c}-0.4888 \\
(0.2862)^{*}\end{array}$ & \\
\hline \multicolumn{4}{|l|}{ Relative Technology Transfer Experience } \\
\hline Lagging cohort & & & $\begin{array}{l}0.5843 \\
(0.3151)^{*}\end{array}$ \\
\hline Leading cohort & & & $\begin{array}{c}0.1233 \\
(0.3550) \\
\end{array}$ \\
\hline \multicolumn{4}{|l|}{ Control Variables } \\
\hline Has medical school & $\begin{array}{l}0.8725 \\
(0.2824)^{* *}\end{array}$ & $\begin{array}{l}0.7408 \\
(0.3146)^{* *}\end{array}$ & $\begin{array}{c}0.1370 \\
(0.3010)\end{array}$ \\
\hline Private university & $\begin{array}{c}-0.3154 \\
(0.2473)\end{array}$ & $\begin{array}{c}-0.0825 \\
(0.3185)\end{array}$ & $\begin{array}{l}-0.6868 \\
(0.2625)^{* *}\end{array}$ \\
\hline Is Carnegie I institution & $\begin{array}{r}-0.2859 \\
(0.3562)\end{array}$ & $\begin{array}{c}-0.7382 \\
(0.4247)^{*}\end{array}$ & $\begin{array}{l}-0.9145 \\
(0.4005)^{* *}\end{array}$ \\
\hline Constant & $\begin{array}{l}3.2896 \\
(0.4573)^{* *}\end{array}$ & $\begin{array}{c}1.5147 \\
(4.096)^{* *}\end{array}$ & $\begin{array}{l}1.5833 \\
(4152)^{* *}\end{array}$ \\
\hline Log likelihood & -75.3535 & -84.5945 & -87.5124 \\
\hline Prob $>\mathrm{chi}^{2}$ & 0.0000 & 0.0028 & 0.0146 \\
\hline$N$ & 62 & 62 & 62 \\
\hline
\end{tabular}

interests divided by the number of active university licenses in 1998. The equity share of active university licenses is thus a fraction that is truncated at zero and bounded by one at the upper level. There are ten cases for which the number of equity deals was zero, which is the lower bound for our data. We therefore use the lower-bound TOBIT model and the number of 1998 licensing agreement is used as an analytic weight in the model to pt-wide robust estimation (Maddala 1983, Greene 2000).

Models 1 and 2 estimates the use of equity as a function of the university's own technology-transfer experience. The results indicate that the university's prior experience in technology-transfer matters in the use of equity. The age of the technology-transfer office is positively related to the university's use of equity as expected. The older the university's office of technology-transfer office the greater the use of equity as a percentage of intellectual property transactions. This result is consistent with Bray and Lee (2000) conclusion, based on interviews at 10 university technology-transfer offices. that offices that have been in existence longer are much more likely to consider taking equity than is a fledgling technology transfer program.

The effect of the cumulative number of licensing agreements on the intensity of equity use is more complex. In Model 1, the cumulative number 
of licensing agreements is negatively related to the intensity of use of equity-the greater the experience with licensing the less likely the university is to make use of equity. In Model 2, we add a quadratic licensing term that is positive and statistically significant. This indicates that the cumulative licensing experience has a nonlinear relationship on the use of equity. Specifically, universities appear more likely to use equity as they gain experience with licensing but the relationship resembles an inverted $U$ as the use of equity decreases when the university has executed a large number of licenses.

Our final measure of the university's own technology-transfer experience is industrial research support. We find that the log of the amount of average annual industrial research support is positively related to the use of equity in Model 2. In sum, we find support for Hypothesis 1.

The effect of the TTO self-sufficiency is of the expected direction for both Models 1 and 2. University technology-transfer offices that are expected to be self-sufficient make less use of equity, ceteris paribus, providing support for Hypothesis 2.

Model 3 estimates the university's intensity of use of equity relative to the technology-transfer performance of peer institutions. The experience of the technology-transfer office relative to other institutions is measured as a dummy variable that is equal to one if the university respectively lags or leads other universities in its cohort in terms of average annual licensing. We find that those universities that lag their cohort make greater use of equity after accounting for structural characteristics. The coefficient for universities that lead their cohorts is of the expected sign but is not statistically significant. This finding suggests that universities that are average relative to their cohort make less use of equity, confirming Hypothesis 3. The coefficient for institutions that lead their cohort. Hypothesis 4, was of the expected sign but not statistically significant.

Our specifications also include structural characteristics and the results suggest universities make greater use of equity deals in technology transfer if they have a medical school. In addition, Carnegie II research universities appear to make greater use of equity. Model 3 reveals that public universities appear to make greater use of equity when they compare themselves to their cohorts.

In sum, the results support the expectation that universities both learn from their own experience and from the experiences of others. We also find that structural characteristics of the university affect the degree to which the university is able and willing to experiment with equity. Notably, universities with medical schools made greater use of equity in licensing agreements. Carnegie II research universities also seemed to be more aggressive in adopting the new mechanism. This fact seems to bear on the relative standing of these institutions and their desire to advance their position.

\section{Conclusions}

Recent trends towards increased university acceptance of equity as compensation for intellectual property rights represents a new strategic perspective on intellectual property management and technology transfer. The older, established view for universities accepting equity in lieu of licensing fees was that equity was the only compensation being offered by cash-starved start-up firms who were the only party that would be interested in the university's patents. We find that equity is increasingly seen by university technology licensing offices as an attractive mechanism that offers advantages in both increasing the upside revenue potential of university technology and improving the alignment between the institution's interests and those of the firm. The adoption of equity may be seem as part of a trend in which universities are becoming more entrepreneurial in light of new opportunities and changing expectations.

These theoretical considerations point to the importance of institutional learning - the product of a university's own experiences and that of other similar institutions, the characteristics of the technology transfer office, and a set of structural variableswhich all affect the degree to which an institution accepts equity as a mechanism in its intellectual property licensing transactions. In this paper, we have developed and tested four hypotheses about the effect of direct experience, organizational incentives, and experience relative to a related cohort on the adoption 
of a new technology transfer mechanism. Our initial results at testing these relationships, using data from a national survey of Carnegie I and II research universities and other measures of academic licensing, support this interpretation.

Our results, though, are limited by both sample size and the absence of attention to changes over time and in university policy. In particular, the recent sharp decline in high-tech stock prices and in IPO share prices may reduce the allure of the equity option. In effect, our view of future trends in university holdings of equity is agnostic. Experience cuts both ways. In many respects, given the recent attention (and hyperbole) associated with university equity initiatives, we would expect the trend to continue, indeed to accelerate. All of our respondents indicated that they expected their university's use of equity would increase or stay the same in the next year. Universities are constantly adapting and learning and our results, and those of other researchers, may relate primarily to the pre-inflexion stage of adoption and diffusion. On the other hand, any prolonged decline in stock prices may quickly lead many technologytransfer offices back into the safe harbor of traditional licensing arrangements. Asking which route may be followed is akin to asking whether it is more profitable in today's market to buy long or sell short. Only time will tell.

\section{Acknowledgments}

We wish to acknowledge funding support from the Andrew W. Mellon Foundation for this paper as part of a larger project on evolving university-industry relationships. This is a collaborative research project and the names of the authors vary between publications although each author makes substantial contributions. We would like to thank Scott Shane, David Mowery, Dan Rodriguez and participants at the Georgia Tech Conference on University Entrepreneurship and Technology Transfer for their comments and suggestions. We are indebted to the technology transfer personnel and research administrators at Johns Hopkins University, The Pennsylvania State University and Duke University for generously sharing their time and expertise in identifying salient issues. We also acknowledge and appreciate the cooperation of the technology transfer officials who participated in our survey. We thank Rolf Lehming and Don Siegel for providing data. The views expressed in this paper are, of course, those of the authors, and do not represent the positions of any of the three universities, the individuals interviewed, or the Andrew W. Mellon Foundation.

\section{References}

Association of American Universities. 1986. Trends in Technology Transfer at Universities. Association of American Universities, Washington, D.C.

Association of University Technology Managers (AUTM) Licensing Survey. 1991-1995, 1996, 1997, 1998, 1999. AUTM, Northbrook, IL.

Bercovitz, J., M. Feldman, I. Feller, R. Burton. 2001. Strategy and structure as determinants of university technology transfer practices: A comparative study. J. Tech. Transfer 26 21-35.

Blake, D. A. 1993. The university's role in marketing research discoveries. Chronicle Higher Ed. (May 12).

Bray, M. J., J. N. Lee. 2000. University revenues from technology transfer: Licensing fees vs. equity positions. J. Bus. Venturing 15 385-392.

Di Gregorio, D., S. Shane. 2000. Why do some universities generate more start-ups than others? Mimeo, University of Maryland, College Park, MD.

Desruisseaux, P. 2000. Universities venture into venture capitalism. Chronicle Higher Ed. (May 26).

Feller, I. 1990. University patent and technology-licensing strategies. Ed. Policy 4 327-334.

—. 1997. Technology transfer from universities. John Smart, ed. Handbook Higher Education, Volume 12. Agathon Press, New York, 1-42.

—, M. Feldman, J. Bercovitz, R. Burton. 2000. A disaggregated examination of patent and licensing behavior at three research universities. Western Economic Association Meeting, Vancouver, B.C., Canada.

Government-University-Industry Research Roundtable. 1986. New Alliances and Partnerships in American Science and Engineering. National Academy of Sciences, Washington, D.C.

Greene, W. H. 2000. Econometric Analysis. 4th ed. Prentice Hall, Upper Saddle River, NJ.

Henderson, R., A. Jaffe, M. Trajtenberg. 1998. Universities as a source of commercial technology: A detailed analysis of university patenting 1965-1988. Rev. Econom. Statist. 81 119-127.

$\rightarrow$ Jensen, R., M. Thursby. 2001. Proofs and prototypes for sale: The tale of university licensing. Amer. Econom. Rev. 91(1) 240-259.

Kahneman, D., A. Tversky. 1979. Prospect theory: An analysis of decision under risk. Econometrica 47 263-291.

Lerner, J. 1999. The government as venture capitalist: The long run impact of the SBIR program. J. Bus. 72 285-318.

$\rightarrow$ Lerner, J., R. P. Merges. 1998. The control of technology alliances: An empirical analysis of the biotechnology industry. J. Indust. Econom. 46(2) 125-156.

Maddala, G. S. 1983. Limited-Dependent and Qualitative Variables in Econometric. Cambridge University Press, Cambridge, U.K.

March, James G. 1988. Variable risk preferences and adaptive aspirations. J. Behavior Organ. 9(1) 5-24.

_ $\rightarrow$., Zur Shapira. 1987. Managerial perspectives on risk and risk taking. Management Sci. 33(11) 1404-1418.

Mowery, D., A. Ziedonis. 1999. The effects of the Bayh-Dole Act on U.S. university research and technology transfer: Analyzing 
data from entrants and incumbents. Paper presented at the Science and Technology Group, NBER Summer Institute, National Bureau of Economic Research, Cambridge, MA.

—, R. Nelson, B. Sampat, A. Ziedonis. 1999. The effects of the Bayh-Dole Act on U.S. university research and technology transfer. L. Branscomb, F. Kodama, R. Florida, eds. Industrializing Knowledge. MIT Press, Cambridge, MA, 269-306.

National Research Council. 1995. Research-Doctorate Programs in the United States: Continuity and Change. National Academy Press, Washington, D.C.

National Science Board. 2000. National Science Board, 2000 (NSB00-1), Arlington, VA.

Rogers, Everett, J. Yin, J. Hoffman. 2000. Assessing the effectiveness of technology transfer offices at U.S. research universities. J. Assoc. Univ. Tech. Managers 12 47-80.

Shane, Scott. 2000. Selling university technology: Patterns from MIT. Paper presented to the Georgia Tech Conference on University Entrepreneurship and Technology Transfer (November).

Siegel, D., D. Waldman, A. Link. 1999. Assessing the impact of organizational practices on the productivity of university technology transfer offices: An exploratory study. Working paper 7256, National Bureau of Economic Research, Cambridge, MA.

Thursby, M., R. Jensen, J. Thursby. 2001. Objectives, characteristics, and outcomes of university licensing: A survey of major U.S. universities. J. Tech. Transfer 12 59-72.

Thursby, J., S. Kemp. 1999. Growth and productive efficiency of university intellectual property licensing. Working paper, Purdue University, West Lafayette, IN.

- M. Thursby. 2000a. Industry perspectives on licensing university technologies: Sources and problems. J. Assoc. Univ. Tech. Managers 12 9-23.

— $-2000 \mathrm{~b}$. Who is selling the ivory tower? Sources of growth in university licensing. NBER working paper no. W7718, Cambridge, MA.

Trajtenberg, M., R. Henderson, A. Jaffe. 1997. University versus corporate patents: A window on the basicness of invention. Econom. Innovation New Tech. 5 19-50.

Tversky, A., D. Kahneman. 1992. Advances in prospect theory: Cumulative representation of uncertainty. J. Risk Uncertainty 5 291-323.

U.S. Patent and Trademark Office. 1992-1999. Technology Assessment and Forecast Report, U.S. Universities and Colleges, 19921999. Information Products Division, Technology Assessment and Forecast Branch, U.S. Patent and Trademark Office, Washington, D.C.

$\rightarrow$ Vonortas, N., H. Hertzfeld. 1998. Research and development project selection in the public sector. J. Policy Anal. Management 17 621-638.

Williamson, O. 1975. Markets and Hierarchies: Analysis and Antitrust Implications. The Free Press, New York.

- 1985. The Economic Institutions of Capitalism. The Free Press, New York.

$-\rightarrow$. 1991. Comparative economic organization: The analysis of discrete structural alternatives. Admin. Sci. Quart. 36(2) 269296.

$-\rightarrow$. 1996. Economic organization: The case for candor. Acad. Management Rev. 21(1) 48-57.

Zacks, R. 2000. The TR university research scorecard. Tech. Rev. 103 (July/August) <http://www.techreview.com/articles/ july00/ zacks.htm>.

$\rightarrow$ Zucker, L., M. Darby, M. Brewer. 1998. Intellectual human capital and the birth of U.S. biotechnology enterprises. Amer. Econom. Rev. 88(1) 290-305.

Accepted by David C. Mowery and Scott Shane; received December 2000. This paper was with the authors 9 months for 1 revision. 